UDK: $81^{\prime} 25$

82.0

821.163.42.09

DOI: https://doi.org/10.18485/25bghun.2021.ch12

\title{
MEDVE ZOLTÁN
}

J. J. Strossmayer Egyetem, Eszék, Bölcsészettudományi Kar, Magyar Nyelv

és Irodalom Tanszék

\section{A poiesis ludizmusa}

\section{A horvát költészeti ludizmus lehetséges tipológizációjáról és fordíthatóságáról}

\section{Összefoglaló}

A költészetben jelentkező játékos horvát irodalom - amit összefoglalóan a ludizmus terminológiájával jelöl a hazai szakirodalom - általános jellemzőinek konszenzusosan a szójátékot, a játék a szavakkalt, a poént és a „dosjetkát” (szellemes megjegyzés) tartják. A horvát irodalomban a ludizmus alkotásainak sokszor az úgynevezett „könnyed versnek” (light verse; laki stih) nevezhetö forma ad otthont. Ezek a versek, a ,poiesis ludizmusának" alkotásai egyszerre több nyelvi szinten kódoltak, egyidőben tartózkodnak a referencialitás és az areferencialitás határán, egyazon időben tradíciókövetők és újítók, játékosan komolyak és komolyan játékosak. A dolgozat célja a ludizmus egy lehetséges tipológiájának felállítása, illetve, ezzel párhuzamosan, a ludista versek fordítási lehetőségének vagy lehetetlenségének felvillantása.

Kulcsszavak: fordítás, horvát irodalom, költészet, ludizmus, tipologizáció.

Jelek ti, világ jelei,

ki tud titeket érteni,

egy ágacskát megfejteni?

(...)

Jelek ti, világ jelei,

biztosan bánunk veletek,

de nem bírunk megérteni.

(Weöres Sándor: Rongyszönyeg 153) 


\section{Játék: nyelv- és szövegjáték}

A játék elméletével foglalkozó irodalmak - s ez a bevezető pár sor éppen csak a jéghegy csúcsát érinti - szinte kivétel nélkül egyetértenek abban, hogy a játéknak mindenekelőtt modelláló és beavató funkciója van; koronként és kultúránként váltakozó hangsúllyal kapcsolódik az ontológiához és az episztemológiához, az etikához és esztétikához.

A horvát irodalom mai napig megkerülhetetlen két játék-teoretikusa Eugen Fink és Roger Caillois. A ,játék világa - írja Eugen Fink a Spiel als Weltsymbol címü könyvében - látszatvilág, képmás-jellegü, s ezért mimézisként határozandó meg (Fink 2000: 261). A játék nem valóságos világa a lét emelkedett szintjéig jut el, felülemelkedik a mindennapok rutinján. ${ }^{1}$ Roger Caillois a játékra a Les Jeux et les Hommes címü munkájában mint az ember világának eleven, aktív részére tekint. A játékot nem az egész világot átfogó entitásként gondolja el, hanem a kultúra különböző jelenségeinek és leképeződésének tartja. Elmélete szerint a játék általánosságban cselekvés, egyedi jegyei lehetnek a szabadság, az elkülönülés, a meghatározhatatlanság, a produktivitástalanság, a szabálykövetés és a fiktivitás (Caillois 1965).

A nyelvjáték fogalmát Wittgenstein ${ }^{2}$ többek közt annak kiemelésére vezette be, hogy a szavak csak cselekvések közé ágyazva és egy tág kontextusban müködnek. A fogalom jelentésébe így nemcsak magát a nyelvet, de a cselekvéseket, gesztusokat, kontextust is bevonta (Neumer 2010: 169-170). „A játék (...) olyan cselekvés, mely kiemelkedik mindennapi életösszefüggésünkből, egyik lényeges jellemvonása az ebből való kiszakadás, és új, a mindennapival

\footnotetext{
${ }^{1}$ Vö. Pavel Florenszkij elgondolását az autentikus ikonfestészetről: „,[a] művészi alkotás során is az történik, hogy a lélek kitör a földi világból s a mennyei világba emelkedik. Ott (...) megtapasztalja a dolgok örök noumenonjait, s feltöltekezvén, a tudás terhétől súlyosan, újból alászáll a földi világba. És itt, a lefelé vezető úton, a földi világba lépés határvonalán, szellemi kincse szimbolikus képeket ölt, olyanokat, amelyekből majd - rögzített formában - létrejön a műalkotás.” (Florenszkij 2007: 21-23)

${ }^{2}$ Mivel a wittgensteini nyelvjáték-fogalom még a Wittgenstein-kutatóknak is - ahogy Neumer Katalin fogalmaz - „csillámló sokértelmüségében” van jelen, a dolgozat nem az eredeti Wittgenstein-szövegekre hivatkozik, hanem csak Neumer adekvát szakirodalmi értelmezéseire.
} 
összehasonlítva tét nélküli életösszefüggés teremtése. A szabálykövetés a nyelvjáték müködésének előföltétele. A nyelvjáték megtanulásához hozzátartozik, hogy a nyelvjáték továbbfejlesztését is megtanuljuk, hiszen ez maga a nyelvjátéknak a játszása. (...) Nyelvjátékaink, szúkebb és tágabb értelemben egyaránt, azaz életformánk egészeként, ill. egyedi beszédcselekvésekként értelmezve is, világföltáró funkciót töltenek be, életünk alapjai" (Neumer 1987: 85).

A játék A szép aktualitása című Gadamer-tanulmányban mint „célnélküli értelmesség” szerepel, amelynek egyik fontos jellemzője az állandó mozgásban levés - mint például a fények vagy a hullámok játéka. A játék végső soron ennek a mozgásnak a megmutatkozása, önábrázolása: „az egyik első lépés az emberi kommunikáció felé vezető úton"3 (Gadamer 1994: 39-40). Gadamer szerint a játék a művészetek területén sem magányos tevékenység. „,...aki ott van egy játéknál, az együttjátszik. (...) A müvészet játékára is érvényesnek kell lennie, hogy a voltaképpeni múképződményt és annak tapasztalóját szétválasztani elvi lehetetlenség” (Gadamer 1994: 46). Az Igazság és módszer „A játék mint az ontológiai explikáció vezérfonala" címü fejezetében a játékot mint a müvészi alkotás létmódját határozza meg. Ontológiai kiindulópontból és az esztétika dominanciájánál maradva igyekszik megszabadítani a játék fogalmát a szubjektív esztétikai jelentésétől - amely a szerző szerint Kanttól és Schillertől kezdve uralkodó nézetté vált -, s objektív esztétikai kontextusba helyezi a fogalmat: „A játéknak saját lényege van (...), a játszás legeredetibb értelme a mediális értelem (...), játszódik valami, valami lejátszódott, valami játékban van. (...) Létmódja tehát az önmegmutatkozás" (Gadamer 1984: 89). S épp ebben az önmegmutatkozásban véli felfedezni a játék és a müalkotás szoros rokonságának egyik fő bizonyítékát. A fenomenológiai megközelítés (Fink, Gadamer) szerint a játék lehetővé teszi, hogy az ember saját magát és világát a szokásostól eltérően is megtapasztalhassa. Ahogy Bacsó Béla írja: „a vélt valóságot képes valódivá

\footnotetext{
${ }^{3}$ A horvát irodalomban legexplicitebben Ivan Slamnig képviseli a játék és kommunikáció
} esszenciális kapcsolatának elvét. 
tenni anélkül, hogy ténylegesen valóság lenne... (...) a világ nem elkülönült és darabjaira töredezett, hanem a mindeneket egybefoglaló módon van” (Bacsó 2018: 829).

Míg Gadamer a játékot a müvészi alkotás általánosabb kontextusában vizsgálja, Wolfgang Iser az irodalmi antropológia felől közelít a fogalomhoz, s az irodalmi szövegre és a nyelvre összpontosít $A$ fiktív és az imaginárius címü könyvének „Szövegjáték” címü fejezetében. Iser szerint a játék lényege struktúráján keresztül ragadható meg: egy az egyben átveszi és az irodalmi szövegre érvényesíti Caillois általános kategóriáit, hangsúlyozva, hogy ezek a szövegekben legtöbbször keveredve jelennek meg. A játék Isernél egy olyan - a nyelven keresztül szinte minden alapvető funkciókat átstrukturáló - performatív, eredménnyel, lezártsággal rendelkező aktus, amely célját elérve véget is ér. A szövegjáték esetében a jelölö kettéhasad, leválik a jelöltről, aminek következtében a jelölő és jelölt közti szemiotikai különbség megkettőződik. „Ha [a szövegjáték] immár nem jelenti azt, amire rámutat, akkor ez az összefüggés maga is rámutatássá lesz, ezzel valami nemlétezőnek adva létet. (...) A meghasadt jelölő játéka nyilván számos módon játszható, mivel az eltörölt transzcendentális jelölt helyét tölti be. (...) [A] kimondhatatlan kimondhatóvá lesz" (Iser 2001: 301-304).

\section{Ludizmus, a poiezis ludizmusa}

A horvát irodalomban legkésőbb a modernizmustól mind a mai napig hangsúlyosan jelen lévő játékosságot, ami a költészetben - a „,poiesisben”: az alkotásban, teremtésben - válik egyértelmüen dominánssá, a hazai szakirodalom összefoglalóan a ludizmus terminológiájával jelöli. A játék/játékosság elméleti alapja köztudottan Platónig, illetve a hermetikus-gnosztikus-kabbalisztikus elgondolásokig vezethető vissza: Isten a komolyság területe, az ember csak játékszer Isten kezében, a misztériumok Istennek szentelt játékok, a logikus ész számára hozzáférhetetlenek; az ember a világ játékába van bezárva, s innen csak akkor szabadulhat, ha felfedezi a játékszabályokat (vö. Hansen Löve 1996: 21). A 
döntően nyelvi meghatározottságú horvát ludizmus - amely a világnak a szigorú logikára alapuló szemléletét szintén nem tartja a megismerés egyetlen érvényes módszerének - szabadulni vágyik, ám a játékszabályokat leginkább saját maga alkotja meg.

A ludizmus szemiotikai, szemantikai játékosságot, ötletességet, improvizációra való hajlamot takar: elemei a szójátékok (,,igra riječi’) vagy játék a szavakkal (,igra riječima”), ${ }^{4}$ a poénok (,poanta”) és a nyelvi, de azon sokszor túl is mutató figurák, a szellemes fordulatok (,dosjetka” [bonmot, witty remark]). Döntő többségében a ludizmusnak ehhez a kategóriájához tartoznak a stilisztikai figurákkal, a trópusokkal, a transztextualitás különböző formáival, a müfajokkal és a versformákkal való játékok.

A következőkben a szöveg a ludizmus fogalmának tipologizációjára tesz kísérletet: a szójáték, a játék a szavakkal, a poénok és „dosjetkák” konszenzusosan a ludizmus területéhez tartoznak, ugyanakkor az úgynevezett könnyed verselés (,light verse”, „laki stih”) átfogóbb poétikai kategóriája a ludizmus fentebbi elemeit a legszofisztikáltabb és legkomplexebb módon képes magába integrálni. Természetesen ritka a tiszta kategória, de a transzparencia kedvéért a jelek piercei felosztásának segítségül hívásával a ludizmus három, sokszor egymásra épülő és egymással keveredő variánsa felvázolhatónak tünik.

\section{Szimbólum: játék a(z egyezményes) jelekkel}

A ludizmus legegyértelmübben behatárolható szintjét a szójátékok, illetve a játék a szavakkal adják. Mindkettő a jelölő és jelölt közti kapcsolattal játszik: a szójáték passzív, a szavakból ered: maga a nyelv fejezi ki, a szavakban meglévő játékosságot, a szavakba kódolt játékosság felfedezését és felmutatását jelenti; a játék a szavakkal teremtő aktus: az alkotótól indul ki, egyéni és egyedi kontextust

\footnotetext{
${ }^{4}$ A horvát szakirodalom a két fogalmat összemossa, holott a szójáték a nyelvben adott, a játék a szavakkal teremtő aktus. Analóg ez Henri Bergson komikum-elméletével, amely a nyelvi komikum két fajtáját különbözteti meg: a nyelv kifejezte, illetve a nyelv teremtette komikumot (Bergson 1986: 99).
} 
hoz létre, sokszor lehetséges világokat is felkínál. A globálist - a világot - formai szempontból rendezi el vagy át. A vers elemei - illetve az elemek egyéniesített változatai - a közös nyelvi tapasztalat miatt legtöbbször fordíthatatlanul simulnak bele az adott nyelvbe. A nyelvjátékra szellemes példa Zvonimir Mrkonjić Contrapuncta címủ verse. Egy részlet a vers kezdetéből:

\section{Rado strada}

radost rada

\section{2. $U$ prirodi}

upri, rodi.

3. Ubij, jedi

u bijedi.

4. Neko pati

ne kopati!

\section{Gori li}

gorili?

\section{Nas motri}

na smotri!...

Kruno Quien Lastovo címü - a játék a szavakkal felé közeledő - versének bevezető részében döntően a szójátékra épít. Az ilyen típusú szöveg a játékhoz tartozó szükebb vagy tágabb korlátok és „szabályok” miatt legtöbbször csak egy fragmentum, vagy fragmentumként ágyazódik a teljes szövegbe. A váratlanul mindenki számára egyértelműen jelentésessé alakuló Lastovo e részletének „fordítása” az esetlegleges fonetikus átíráson kívül semmi mást nem igényel:

\footnotetext{
${ }^{5}$ Fontos szempont volt minél több olyan vers idézése, amelynek van magyar fordítása, így ezekben az esetekben ugyan mindig adekvát, de nem egyszer nem a legadekvátabb alkotások kerültek be illusztrációként a szövegbe. A hivatkozott versek döntő többségének - érthetően - nincsen magyar változata, így a horvát vagy szerb nyelvet nem ismerő olvasók sajnos sok esetben csak az alkotások formai-akusztikus vetületére hagyatkozhatnak.
} 


$$
\begin{aligned}
& \text { Do } \\
& r e \\
& m i \\
& f a \\
& \text { sol } \\
& \text { la } \\
& \text { sto } \\
& \text { vo }
\end{aligned}
$$

A játék a szavakkal dominanciájú TE TA TI TA TI címü Kruno Quien-vers elemeinek egy része jelentéses, a többi esetében a jelentéses elemekhez illeszkedő kontextuális - és ezért fordíthatatlan, esetleg az egész egységet a célnyelvre transzponálható - jelentésről az olvasó dönt:
Teta ti tati
leti
tata ti leti
teti
Teta ti tatu
tuti
tata ti tetu
teti

Teta ti tatu ti

tata ti tetu ti

\section{Index: a játék a valóságra referál}

A poénok és az úgynevezett dosjetkák kisebb-nagyobb hangsúlyeltolódással már az irodalom kezdetétől fogva jelen vannak a horvát irodalomban is, különösen azokban a korszakokban, amelyekben az eredetiség, a szubjektivitás kifejeződésre 
juttatása dominál. Ezek az alakzatok nem a szójátékra vagy a játék a szavakkalra építenek, hanem döntően - Freud vicc-elméletében szereplő jellemzőkhöz hasonlóan - a kontradikcióra, a váratlanra, a „külcsín” és a „belbecs” viszonyára, az egymástól függetlennek tűnő entitások közötti kapcsolat felmutatására koncentrálnak; a poén és a dosjetka ebből a szempontból esetenként már a poiesis ludizmusát is megelölegezik.

Luko Paljetak a „külcsín” és a „belbecs” kettőségénél továbblép a Stonoga (Százlábú) című „epikus” versében, amelyben a vers mint müalkotás és a „verstárgy” látszatra és az átlagos „elvárásszint” alapján inkompatibilis viszonyát rendeli egymáshoz némi öniróniával:

\author{
Stonogu vidio sam na zidu dok sam mokrit \\ išao u naš stari i otrcani zahod; \\ iznenađena svjetlom zastala je, a ja sam \\ mokreći gledao je; ugasio sam zatim \\ svjetlo i otišao, i sada ovo pišem \\ držeć da to je važno
}

A szintén a mindennapokat tematizáló, alkalminak tünő Brodeto i kravata (Halragu és kravátli) címủ Slamnig-vers a látszat ellenére rétegzett alkotás: a „horvátság” örök kérdésének sokszor lázongó, kontroverzív jellege mellett (A. G. Matoš, Miroslav Krleža, Ivan Slamnig, Boris Maruna stb.) egy másfajta, játékos szemléletmódot kínál fel, amelyben többek közt majd Luko Paljetak és Boris Maruna is osztozni fog. A vers a referencialitása miatt viszonylag könnyen átültethető más nyelvekre, ugyanakkor lexikai szinten problémákat vet fel: a „kompleks” szó elsősorban történelmi-irodalmi beágyazottsága, illetve a „brodeto” és „kravata” döntően nyelvi-kulturális háttere miatt a fordításban nehezen, illetve a denotatív szinten maradva adható csak vissza: 
Neki dan dok sam smireno

griskao Albert kekse,

ustanovih da mi to što sam Hrvat

nabija komplekse.

Što su Hrvati dali svijetu

da mi je samo znati?

Topi se, Hrvo, u brodetu,

visi o kravati.

\author{
Egy nap mikor nyugodtan \\ rágtam az Albert kekszet, \\ rájöttem, horvát voltom csen belém \\ egynémely komplexet. \\ A horváttól, eben guba, \\ mit kapott a világ barátim? \\ Fulladj Hrvo halraguba, \\ lógj egy kravátlin.
}

(Csordás Gábor ford.)

\section{Ikon: az (ön)azonosság felmutatása - a poiesis ludizmusa ${ }^{6}$}

A horvát irodalom a világ és a szerző saját énjének közös nyelvi tapasztalatára építő ludizmusában igen gyakran a W. H. Auden után a már említett könnyed versnek nevezett formák adnak otthont az alkotások inventív, humoros-ironikus alakzatainak: a szójátékoknak, a játék a szavakkalnak, a poénoknak, és a dosjetkáknak. A nyelvi ludizmust leginkább a világ egy szegmentuma: a jelölő és a jelölt viszonya foglalkoztatja, a könnyed verselés és a ludizmus találkozása amire innentől kezdve mint a poiesis ludizmusára hivatkozunk - a világ soha meg nem ismerhető teljességének átfogására történő irányultságot és igyekezetet célozza meg, azt, ami a szavakon túli kimondásának vágyaként és egyúttal lehetetlenségeként van jelen minden nyelvben. ${ }^{7}$ A poiesis ludizmusának szerzői az egyetlen rendelkezésükre álló módon, a nyelv segítségével próbálják meg a teremtés aktusát utánozni, s ezzel rámutatnak arra, hogy ahhoz a nyelven keresztül a legjobb esetben is csak közelebb lehet kerülni.

\footnotetext{
${ }^{6}$ A bekezdés néhány gondolatát a Paródia, pszeudonimia, ludizmus című írásomból vettem át (Ex Symposion, 2018/100, 80-85).

7 „Minden nyelv elhallgat némely dolgot, hogy elmondhasson mást. Mindent tudniillik nem lehet elmondani” (Ortega y Gasset 2000: 144).
} 
A könnyed vers szerzői nem lépnek ki átlagember mivoltukból, a versek nyelve világos, érthető: könnyed („laki”). Az ilyen nyelven történő megszólalás pedig - már csak strukturáltsága miatt is - vers (,stih”) lesz. Ahol kommunikáció van, mondja Slamnig, ott költészet is van: már maga az, hogy nyelvet használunk, hogy beszélünk - költészet (vö. Donat 1983). A könnyed verselésü mü leginkább az adott idő kollokviális nyelvén szólal meg, s a deiktikusságát szupraszegmentális elemeken keresztül: a zeneiség, a ritmus és a rímek hangsúlyosságával tágítja, és bizonytalanítja el.$^{8}$ Ez a kettős irányultság, amely tökéletesen funkcionál az adott nyelven, nem vagy csak igen kivételes esetekben és kérdéses eredménnyel vihető át a szubjektum és a világ együttélésére kisebb vagy nagyobb mértékben szükségszerüen másként tekintő célnyelvre.

A könnyed verselés a modern horvát költészetben tulajdonképpen már A. G. Matoš Mora címü hosszúversének kezdetén - E. A. Poe A hollójának, s ezzel együtt a róla írt esszéjének áthallásával - formai szempontból megjelenik, ugyanakkor a részlet verselésének vészjósló könnyedsége természetesen nem ludista, hanem balladai:

\section{Unoćni sat}

Ušo je ko tat...

U kutu čuči,

Došo je, da muči,

Da mi kosti toči, oči kljuje,

Udara na muke, crven lanac kuje...

Matošéhoz hasonló verselésủ Tin Ujević szintén kanonikus, de autoreflexív, a ludizmushoz is közeledő - a befogadótól függően: finom autoreflexióra és

\footnotetext{
${ }^{8}$ Néha már-már az „onto-episztemológiai szinesztéziát” súrolva, mint Boro Pavlović Evanđelje po pjesniku (A költő evangéliuma) címü ötsorosában: U početku bijaše Riječ. / Riječ bijaše u Slici. /I Slika bijaše u Zvuku, i / Slika bijaše Riječ. / I Riječ bijaše Sve. (Kezdetben vala a Szó. / A szó vala a Képnél. / És a Kép vala a Hangnál, és a / Hang vala a Szónál. / És a Szó vala Minden.) - A Pavlovićvers első sora szó szerint a horvát nyelvü János-evangélium kezdetét ismétli.
} 
öniróniára is hajló - verse, a Svakidašnja jadikovka (Hétköznapi sirámok). Példaként csak a vers utolsó két versszaka:

Jer mi je mučno biti slab,

jer mi je mučno biti sam

(kada bih mogao biti jak,

kada bih mogao biti drag),

no mučno je, najmučnije

biti već star, a tako mlad! ${ }^{9}$
Mert gyötrö már a gyengeség, mert gyötrö lennem egymagam, (mikor lehetnék nagy s erös, mikor lehetnék kedves is) de gyötrö, leggyötrelmesebb, hogy vén legyek s íly fiatal.

(Csuka Zoltán ford.)

A „laki stih” egyik legparadigmatikusabb horvát szerzőjének, Boro Pavlovićnak az Igrati se (Játszani) című verse primér szinten tulajdonképpen az elmúlás toposzát teszi játékosan és a játékot magát is tematizálva egyedivé és familiárissá, fokozatosan és minden didaxis nélkül elfogadottá, az élet szerves részévé. A kollokviális nyelvhasználatnak és a lágy ívű sorok mesterkéletlenségének is köszönhetően a vers adekvát magyar fordítást kapott:

$$
\begin{aligned}
& \text { igrati se smijati } \\
& \text { igrom neodigranom } \\
& \text { sa tom zvečkom razbitom } \\
& \text { sa tom dobrom mačkicom } \\
& \text { igrati se kroz sebe } \\
& \text { od podneva sve do dna } \\
& \text { izvan sebe kraj sebe } \\
& \text { kao male zebe }
\end{aligned}
$$

$$
\begin{aligned}
& \text { játszani nevetni } \\
& \text { játszatlan játékkal } \\
& \text { ezzel a törött zörgéssel } \\
& \text { ezzel a jó kis macskával } \\
& \text { játszani magunkon keresztül } \\
& \text { magas naptól amíg sötétül } \\
& \text { magunkon kívül megunk mellett } \\
& \text { ahogy a kicsiny pintyek }
\end{aligned}
$$

\footnotetext{
${ }^{9}$ A ritkábban Matošnál is megtalálható autoreflexió és önirónia például a Lakrdijaš címủ versében (1. később) párosul a könnyed verseléssel. Az Ujević-vers fordításának nehézségeire utalhat az a tény is, hogy az idézett mellett még négy magyar fordítása olvasható: Ács Károlytól (Mindennapos panaszdal), Dudás Kálmántól (Mindennapi siránkozás), Fehér Illéstől (Mindennapos kesergés) és Szenteleky Kornéltól (Mindennapi sirám).
} 
igrati se letjeti

kao vrijedni leptiri

što sustanu tek kad ih

hladna večer umiri játszani repülni

mint a szorgos lepkék

akiknek akkor nyugszik a röpte

ha lehüti öket az este

(Ladányi István ford.)

A könnyed és biztos kezet igénylő verselés és a népi-népies ludizmus találkozásának kiváló példája A. G. Matoš Lakrdijaš - Karnevalski calembour (kb. Tréfacsináló/Buffó - Karneváli kalambur) címü szonettje. A különböző kultúrákban valamilyen formában általában megtalálható karneváli forgatagot idéző vers lényege, a - némi tényleges vagy tettetett keserüséggel átitatott bolondozás átültethető más nyelvre, a lexikája a végletekig hangsúlyozott sorvégi és belső rímek miatt ugyanakkor a célnyelvektől függően szinte teljesen biztosan mások és mások lesznek:

Teško je kad imaš mnogo duha,

Još je teže kada nemaš kruha;

Teško sluhu kada je bez uha,

Teško uhu kada je bez sluha.

Teško onom koga muči muha,

Teže onom koga grize buha:

Teško biću kojemu se kuha

Vječan ručak - samo posna juha.

Teško onom koji poput puha

Vonja pored dame fina njuha!

Teško i onom što na rimu , ruha”, 
Mora sricat ,ćcuha”, ,, stuha”, ,,gluha”,

Svršivši sonet u počast potepuha,

Princa Karnevala, Petra Kerempuha.

A karnevál hercegével más kontextusban Miroslav Krleža egyik legismertebb, évszázadok történelmét és tapasztalatait is feldogozó Balade Petrice Kerempuha (Éjtszakának virrasztója. Petrica Kerempuh balladái) címü kötetében találkozhatunk újra. ${ }^{10}$ A Khevenhiller címü versének semmitmondó közhelyből induló, keserü bőbeszédüséggel viccelődő, ugyanazt ismételgető első felére Nigdar ni tak bilo /da ni nekak bilo, / pak ni vezda nebu / da nam nekak nebu... (Soha úgy még nem volt, / hogy valahogy nem volt, / így hát sohasem lesz, / hogy valahogy nem lesz... [Csuka Zoltán ford.]) - majd más kontextusban, a szubjektum erőteljesebb előtérbe állításával és a részben dialektusos nyelvezetével Slamnig Navek je nekak bilo (Valahogy vót azér) című versének egy részlete fog rímelni: Kako god nas je rezalo / navék je nekak bilo / šljive su bile plave / jaje je bilo bilo. (Akárhogy vágtak minket, / valahogy vót azér, / a szilva mindig kék vót, / a tojás meg fejér... [Csordás Gábor ford.]).

A poiesis ludizmusában az archaizálás (Petrica Kerempuh balladái) és a dialektusosság (Valahogy vót azér) mellett szinte hagyománynak nevezhető az idegen nyelvi elemek, sokszor teljes szintaktikai és szemantikai egységek, szövegrészletek átemelése, illetve beágyazása a versbe. Amennyiben idegen nyelvü teljes szemantikai egység emelődik át a versbe (például Slamnig Alba címü verse [1. később]), fordítására semmi szükség, amennyiben „szórvány” vendégszövegként mintegy hibrid nyelvet létrehozva szerepel - mint például a Pjev za Feniksa (Ének a Főnixért) címü Josip Sever ludistának ugyan nevezhető, ám nem könnyed verselésü verse, amelyben a szerző nem csak grafémákkal és

${ }^{10}$ Csuka Zoltán értő fordítása előtt leküzdhetetlen akadályok álltak: a könnyed verselés, a 16. századbeli autentikus kaj nyelvjárás, az irónia, a paradox, a szarkazmus, a groteszk és az abszurd hangvétel. Mindezek miatt a versek bármely nyelvre történő fordításai törvényszerủen messze fognak esni az eredetitől; talán nem nagy túlzás megkérdőjelezni a Petrica Kerempuh... bármely nyelvre történő fordításának értelmét. 
fonémákkal, de még a saját nevével is játszik - fordítása szinte lehetetlen: „iks und tot / severus gott / (latinsko-gotički motto) // ako je strogi bog ili severus gott / za ptic u feniks pticu što kaže niks frštee / za svoje uskrsnuće svoj pepeo i sjaj / iks und tot il smrt i nepoznato...

Kontextualizált idegen nyelvü vendégelemekkel a horvát költészetben talán Ivan Slamnig verseiben találkozunk a leggyakrabban. Az egyúttal a ludizmus egyik forrásaként is funkcionáló idegen nyelvü elemek hol a vers igényelte módon az adott nyelven (pontosan) el nem mondható legalább részbeni elmondása, hol az adott poétikai keretek közt kifejthetetlen kifejtése miatt jelennek meg. A szerelmesek hajnali kényszerü elválására müfajilag is utaló Alba címü vers első sorát egy angol gyermekversből, a másodikat egy 19. századi német nyelvü egyházi énekeskönyvből emelte át, míg a harmadik sor egy sevdalinka (eredetileg a boszniai muzulmánok szerelmes éneke) kezdő sora, s az utolsó („Akarod/Akarsz még egyszer? Rajta) Slamnig poénja, amely a gyermekvershez visszacsatolva zárja be a kört:

To bed, to bed, my curly head, wir müssen uns jetzt scheiden, jer zora rudi, dan se bijeli. Hoćě̌ još jednom? Hajde. ${ }^{11}$

Tin Ujević Cjeloviti cjelov i Ti (fordíthatatlan játék a szavakkal, szó szerint: Teljes csók és te) címü versének mikrokozmoszbeli makrokozmosza - hasonlóan azt ezt követő Slamnig-vershez - kiválóan illusztrálja a poiesis ludizmusát; a

\footnotetext{
${ }^{11}$ A vers angol és német nyelvü sorai - mindkét nyelvnek hagyományosan kissé más pozíciója és funkciója van a horvát nyelvben, mint például a magyarban - nyilvánvalóan nem fordítandók. A harmadik, horvát nyelvủ sor müfaji-kulturális vonatkozásai miatt más nyelvre történő átvitel esetében csak részben lehet adekvátan dekódolható és kódolható, az utolsó, mindenekelőtt a két idegen nyelvű sorral kontrasztos egyetlen eredeti slamnigi sor poén jellege így egyrészt az előtte lévő idézet líraiságával való szembenállásának kollokvialitásából, másrészt pedig a vers kezdetéhez való visszakapcsolásból következik.
} 
könnyed sorok közül a vers poénját adó befejező két sor nemcsak a játék a szavakkal, de a poénra kifutásnak is egyik tökéletes példája:

Svojim dahom ti si svijet jezgroviti

kamo će se sloge boja sliti.

Ja ću tebi vijence viti,

draganjima oviti,

i tada će opet biti

u potpunoj kiti

cjeloviti

- Cjelovi Ti.

Ivan Slamnig Kad mi svega bude dosta (Amikor mindenből elegem lesz) formai/nyelvi játékossága nem tematizálja a játékot: magán a formán keresztül individualizálva teszi a Játszani címü Pavlović-vers vershelyzetét - a könnyedség mellett a kollokviális nyelvhasználat segítségével - játékossá és bölcsen (ön)ironikussá, s így - szükségszerü veszteségekkel - még esetleg transzferálhatóvá is:

Kad mi svega bude dosta

evo oči, da ću poći

$k$ onome što dolje osta.

Ne ću činit više, bome

ono, što do sada morah,

sjesti ću pod stari orah

(sličan onom pokojnome!)

stol će prostrt bit bjelinom,

za nj ću sjesti, pa ću jesti

kruh sa sirom, ribu s vinom. 
A kortárs horvát költészet egyik kiemelkedő formamüvésze a kilétét a kezdetektől fogva titkoló Sven Adam Ewin - akinek ,a verseiben a nyelv és a világ a szemünk elött születik meg újra" (Bagić 2015: 6) - a poesis ludizmusának talán egyik legizgalmasabb, szintetizáló és ezzel együtt mindig a saját útját is járó szerzője. A ténylegesen és/vagy tettetve az elődei nyomdokain haladó verseiben sokszor klasszikus szerzőkhöz és formákhoz tér vissza, s - a magyar irodalomban talán leginkább Kosztolányihoz hasonlóan - az amatőrizmus és profizmus határán táncolva, de mindig a profizmuson belül maradva fogja vallatóra a tradíció(ka)t. ${ }^{12}$ A poiesis ludizmusának lényegi jellemzőit a posztmodern tapasztalatával - és azon túllépve - reflexív és autoreflexív módon használja fel: a nem mindig szembeötlő kulturális csavarokon keresztül is referenciális alkotások finoman parodizálják, kiforgatják az irodalmi hagyományt: a szerző ironizál velük/gúnyolódik rajtuk - és ezzel együtt saját magán is.

Ewin versei a tradíciókon, szerzőkön, műveken keresztül többszörösen is ludisták: a referencialitás és a játékos irónia-önirónia párhuzamos jelenléte engedi ugyan a fordítást, de az irónia „mihez képest” folyamatosan felszínen tartott kérdése miatt az esetek többségében bizonyos formai vagy tartalmi szintek még a legautentikusabb áttétel esetében is szükségszerüen elhalványulnak, sokszor

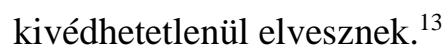

A Stilska vježba (Stílusgyakorlat) címü versének kezdete mintha Ujević Bura na Вraču címü versének - amelynek kezdete Matoš Morájat és Poe sokszor magyarra fordított $A$ hollóját is felidézi - ellenpontja lenne:

\footnotetext{
${ }^{12}$ Csak egyetlen, az Észlelési gyakorlatok címủ antológiában (Tiszatáj Könyvek, Szeged, 2017) magyarul is olvasható példa: az Utjeha pjesme (A vers vigasza) Matoš egyik legismertebb, az Utjeha kose (A haj vigasza) címü versére, valamint az Utjeha kaosa címü, kortárs horvát költészeti antológián keresztül az egész kortárs horvát költészetre is alludál. (Az antológia magyar kiadása: $A$ káosz vigasza. Jelenkor, Pécs, 2009).

${ }^{13}$ Ewin műveiből csak néhány, nem minden esetben a legtipikusabb, de Fenyvesi Ottó autentikus fordításában magyarul is olvasható verse, illetve versrészlete szerepel illusztrációként.
} 
Kad lahor grli more,

tad vali zamrmore:

More amore... more amore...

Brnistra se rasprostire

Uz Postire.

U frulicu pastir svira

Kraj Postira.

Pastir svira gore, usred gore,

Usred gore, borovi šumore.

Vinogradi

Besprizorno

Zore...

S a Tin Ujević-vers két részlete:

U prozore $i$ vratnice

lupa bura tmurnih ura;

dršću male dvokatnice.

Bura. Bura. Bura. Bura.

(...)

Uz obalu stabla gura.

Vjetar gruva, grmi: hura!

Ko bi zvučna duša bila

razapeta povrh krova?

Odgonetah: ti si vila

Mosora i Biokova...
Amikor a szellövel ölelkezik a tenger,

a hullámok azt suttogják:

amore mio... amore mio...

Elnyújtózik a seprü

Posztirán.

Pásztor fújja pikuláját

micsoda pasztorál Posztirán

fönt, fönt magasan

a fenyvesekben,

zúg az erdö.

A szölöskerteken át

magányosan

jön a hajnal... 
A Stílusgyakorlat utolsó három verszaka ironikusan reflektál Vladimir Nazorra, illetve a bloomi hatásiszony fogalmára:

Grčak grče navrh trna.

Trčak trče preko srče,

A na čvoru crne smrče...

"I cvrči, cvrči cvrčak na čvoru crne smrče

Svoj trohej zaglušljivi, svoj zvučni teški jamb...«

I cvrči, cvrči, cvrči,

A mene тис̆i:

Cvrči li to cvrčak stvarni

(Rod cikade)?

Il' to cvrči reinkarni

Rani Vlade?

Od tog (koji nije stvarni)

Imam zazor,

Jer me straši reinkarni

Rani Nazor.
Bütyköli a bütykeit a bütyök, iszkol a tücsök a tüskésben. A fekete boróka bogyóján ... „És húzza, húzza a kabóca a fekete fenyö csomóján

fülsiketitö trocheusát, súlyosan hangzó jambusát..."

És ciripel, ciripel, ciripel.

Én meg cipelem a kérdést:

Vajon tényleg kabóca-e az, mi ciripel

(félfedelesszárnyúak rendje)?

Vagy a fiatal Vladimir

reinkarnációja?

Ettöl kirázna a hideg

(ha mégsem igazi)

mert félnék a fiatal Nazor

szellemétöl.

A Zaborav (Feledés) címü versben nyelvileg-formailag is hangsúlyozza a tudatalatti tudatossá formálódásának kezdeti fázisát, s ezzel párhuzamosan a könnyed verselés még szüz és zavaros „nyersanyagát” is felmutatja. A formálódót (a költészetet) és a formáló médiumot (önmagát) félig tudatosan (félálomban) vezeti Slamnig Kad mi svega bude dosta címü versének lehet, hogy csak átmenetileg, de az adott helyzetben végsőnek tủnő, otthonos valóságba: 
noćas u krevetu vrtim

u glavi neke slike kad

mi iznenada padne na

pamet jebeno dobar st

ih za novu рjesmu plu

s još jedan pa još jeda

n to su tri a već

(...)

slobodni stihovi

će se tada smiriti kao $i$

vali što se smire a ti će

$\check{s}$ i i imati na sto sto sto

lu svježi obrok sve sve

sve sve sve svenove po

ez z z z z zije u tartartar

umaku s ka ka kaduljom

i vinom koje može biti i crno. uh
Forgok az ágyban ma éjjel

nyugtalanul forgok fejem

ben képek rajzanak és ak

kor bevillan egy kurva jó s

or amiböl vers lesz érzem

és még egy és még egy jön

ez már három

(...)

álmodban a szabadversek

megnyugszanak ahogy a hul

lámok is lecsillapodnak

és reggelre kelve az asz

talon fenséges reggeli

vár vad vadon vadonatúj

költészet vagy poézis tar

társzószban zsályával és

borral ami lehet akár vörös is. uhh.

A poiesis ludizmusának - a horvát költészetben legalábbis - talán legfontosabb vonásai, hogy illuzórikus jellegük miatt a kapott összbenyomás legtöbbször finom parodisztikus vonásokat is hordoz. A müvek egyszerre több nyelvi szinten kódoltak, a referencialitás és az areferencialitás határán tartózkodnak, egyazon időben globálisak és lokálisak, egyetemes és nemzeti kultúra-függők és bekebelezők, tradíciókövetők és újítók, játékosan komolyak és komolyan játékosak. Boro Pavlović írja a könnyed verselésű vers medialitásáról: ,a vers nem születik, hanem megtörténik"; a vers a szavakban, s nem a gondolatokban jelenik meg, a szavakból, s nem a gondolatokból bukkan fel - s ezek a szavak levegőt követelnek maguknak. „A verset nem írják, hanem vadásszák. Elkapják. A vers 
vár. Megvár. A versnek mindig megvan a teste, a vers a maga homályosságában válik igazán világossá" (Pavlović 2006).

A könnyed versben, különösen a poiezis ludizmusának verseiben benne van a kezdet és a vég, az etika és esztétika egybeesik, ontológiából észrevétlen episztemológiába fordul, illetve episztemológiát ír és ontológiát olvastat. Az alapvető emberi tapasztalatok hozzávetőlegesen hasonlók, ám a költő nyelvben lakozása határokat állít fel: nyelvenként változó, ami a közhelyesség gyanúja nélkül még kimondható; amit a horvát poeta ludensek - különösen az úgynevezett könnyed vers, a poiesis ludizmusa - versei bölcsen sugallnak. Radnóti Sándor Varró Dániel verseiről írt szavait parafrazeálva: az élet és a költészet egyszerre megismételhetetlen, kimondhatatlan, transzferálhatatlan (a költészet esetleg transzponálható), és az is meglehet, hogy nem is olyan nagy dolog, mint ahogy azt gondoljuk:

kad budeš gol i svet, novorođen $i$ razapet,

kad budeš bio bol i put, kad budeš tren neutrnut,

kad budeš star, kad budeš leš, kad budeš bio biti ćeš. ${ }^{14}$

\section{Bibiliográfia}

Bacsó Béla 2018. A játék mint mű és világfenomén. Jelenkor 7-8, 828-835.

Bagić, Krešimir 2015. U svijetu tekstova. Vijenac 24, 6.

Bergson, Henri 1986. A nevetés. Budapest: Gondolat Kiadó. Szávai Nándor fordítása.

Caillois, Roger 1965. Igra i ljudi. Beograd: Nolit. Preveo Radoje Tatić.

\footnotetext{
${ }^{14}$ Részlet Kruno Quien Radovanova vrata címủ költeményéből.
} 
Donat, Branimir 1983. Ivan Slamnig. In: Ivan Slamnig: Izabrana djela. Zagreb: Nakladni zavod Matice hrvatske. 7-37.

Fink, Eugen 2000. Igra kao simbol svijeta. Zagreb: Demetra. Prevela Darija Domić.

Gadamer, Hans-Georg 1984. Igazság és módszer. Budapest: Gondolat. Bonyhai Gábor fordítása.

Gadamer, Hans-Georg 1994. A müvészet mint játék, szimbólum és ünnep. In: HansGeorg Gadamer A szép aktualitása. Budapest: T-Twins Kiadó. 11-84. Bonyhai Gábor fordítása.

Hansen Löve, Aage A. 1996. Umjetnost kao igra. Modeli ludizma između romantizma i postmodernizma. In: Živa Benčić \& Aleksandar Flaker (eds.) Ludizam. Zagrebački pojmovnik kulture 20. stoljeća. Zagreb: Zavod za znanost o književnosti Filozofskoga fakulteta Sveučilišta u Zagrebu-Slon. 19-33. Prevela Elvira Ratković.

Iser, Wolfgang 2001. A fiktív és az imaginárius. Budapest: Osiris Kiadó. Molnár Gábor Tamás fordítása.

Neumer Katalin 1987. Nyelvjáték és tradíció. Ludwig Wittgenstein késői filozófiájának értelmezéséhez. Filozófiai szemle 1, 81-111.

Neumer Katalin 2010. A nyelvjátékok konstituálják-e a tényeket? In: Gábor György \& Vajda Mihály (eds.) A lét bonyolultsága. Tanulmányok a tudás sokféleségéröl. Budapest: Typotex. 162-174.

Ortega y Gasset, José 2000. A fordítás nyomorúsága és nagyszerűsége. In: José Ortega y Gasset Hajótöröttek könyve. Budapest: Nagyvilág. 127-158. Scholz László fordítása.

Pavlović, Boro 2006. Slika, zvuk, stih. In: Boro Pavlović Ljepota riječi. Zagreb: Disput. 53-96. 


\title{
The Ludism of Poiesis
}

Zoltán Medve, Josip Juraj Strossmayer University of Osijek, Faculty of Philosophy, Department of Hungarian Language and Literature

\begin{abstract}
The author of this paper examines the so called ,poems of ludism” in the playful Croatian literature. In the Croatian literature, the terminology „ludism” mostly refers to the playful poems which contain plays of words, puns, points, witty remarks. The Croatian poems of ludism often dwell in the form of light verse. Due to the combination of ludism and light verse (,ludism of poiesis”), these poems are encoded at more language levels. They are on the borderline of referentiality and areferentiality, they follow the traditions and they are innovative, seriously playful, and playfully serious at the same time. Besides the attempt to typologise poems of Croatian ludism, the aim of this paper is to refer to their (un)translatability.
\end{abstract}

Keywords: Croatian literature, ludism, poetry, translation, typologization.

\section{Ludizam poiesisa}

Zoltan Medve, Sveučilište Josipa Jurja Strossmayera u Osijeku, Filozofski fakultet, Katedra za mađarski jezik i književnost

\section{Sažetak}

Općom karakteristikom razigrane hrvatske poezije, koju domaća literatura označava terminologijom ludizma, konsenzusno se smatra igra riječi, igra riječima, poanta i dosjetka. U hrvatskoj kniževnosti, književna stilska formacija tzv. lakog stiha (light verse) često „udomljava” djela ludizma. Djela ludizma kodirana su i na više jezičnih razina: istovremeno borave na granici referencialnosti i areferencialnosti, poštuju tradicije i služe se neologizmima, ozbiljno su razigrana i razigrano su ozbiljna. Cilj je priloga postaviti moguću tipologizaciju ludizma te, paralelno s tim, ukazati na (ne)prevodivost pjesama hrvatskog ludizma.

Ključne riječi: prevođenje/prijevod, hrvatska književnost, ludizam, poezija, tipologizacija. 